\title{
Range extension and morphological characterization of rhodolith-forming species (Corallinales, Rhodophyta) from shallow water in the Mexican South Pacific
}

\author{
Edith Concepción Peralta-García • \\ Edgar Francisco Rosas-Alquicira
}

Received: 31 December 2013/Revised: 11 July 2014 / Accepted: 15 July 2014/Published online: 29 July 2014

(C) Springer-Verlag Berlin Heidelberg and AWI 2014

\begin{abstract}
Living rhodolith beds are widely distributed along the Eastern Pacific ocean. Despite their widespread distribution, little is known about the rhodolith-forming species from shallow water in the Mexican South Pacific. Many taxonomic and morphological studies about rhodoliths have been carried out in the Gulf of California, where the forming species belong to the Hapalidiaceae and Corallinaceae families. This paper is the first report on the occurrence of the rhodolith-forming Hapalidiaceae species Lithothamnion muelleri and Phymatolithon repandum at three sites in the Mexican South Pacific. The branch density, maximum length and sphericity were measured for each determined species. Rhodoliths were distributed between 4 and $6 \mathrm{~m}$ depth, but differences in the branch density between species and sites were not found. Finally, the present record of L. muelleri fills the gap in the species distribution along the Eastern Pacific ocean, while the record of $P$. repandum is the first of the species in the region.
\end{abstract}

Keywords Branch density - Lithothamnion muelleri . Phymatolithon repandum - Sphericity · Taxonomy

Communicated by F. Weinberger.

E. C. Peralta-García

Programa de maestría en Ciencias, Departamento de recursos del

Mar, Cinvestav-IPN, Unidad Mérida. Antigua carretera a

Progreso Km 6, Cordemex, C. P. 97310 Mérida, Yucatán,

Mexico

E. F. Rosas-Alquicira $(\bowtie)$

Instituto de Recursos, Universidad del Mar, Campus Puerto

Ángel. Ciudad Universitaria, C. P. 70902 Puerto Ángel, Oaxaca,

Mexico

e-mail: cocol_rosas@hotmail.com; erosas@angel.umar.mx

\section{Introduction}

Rhodoliths are free-living structures composed mostly $(>50 \%)$ of non-geniculate coralline red algae. Rhodoliths have ecological, economic and paleoenviromental importance (Foster 2001). Species that form rhodoliths usually cannot be identified with certainty using only variations in growth form or external morphology. Accurate and reliable identification requires the examination of vegetative and reproductive characters (Harvey and Woelkerling 2007).

Living rhodolith beds are widely distributed along the Eastern Pacific Ocean, and they are particularly abundant in the Gulf of California (Foster 2001). Many taxonomic studies have been carried out in the Gulf of California, where the forming species belong to the Hapalidiaceae and Corallinaceae families (Steller et al. 2009). Little is known about rhodolith-forming species in the Mexican South Pacific. Although there are several papers that report the presence of non-geniculate corallines in the area (i.e., Dawson 1960; León-Álvarez and González-González 1993; León-Tejera and González-González 1993; Mendoza-González and Mateo-Cid 1998; Mateo-Cid and Mendoza-González 2012), only Fragoso and Rodríguez (2002) register the rhodolith-forming species, Lithophyllum frondosum and Spongites fruticulosus, but without describing their morphological features.

As far as it is known, in the Mexican South Pacific, rhodoliths occur in Playa Manzanillo and Playa Carey in Ixtapa-Zihuatanejo, Guerrero and Isla Cacaluta in Huatulco, Oaxaca, Mexico. However, the species composition and descriptive morphological characteristics of the rhodoliths in these places are unknown. The current study aims to describe rhodolith-forming species, with respect to growth form, branch density, maximum length and sphericity at three sites in the Mexican South Pacific. 


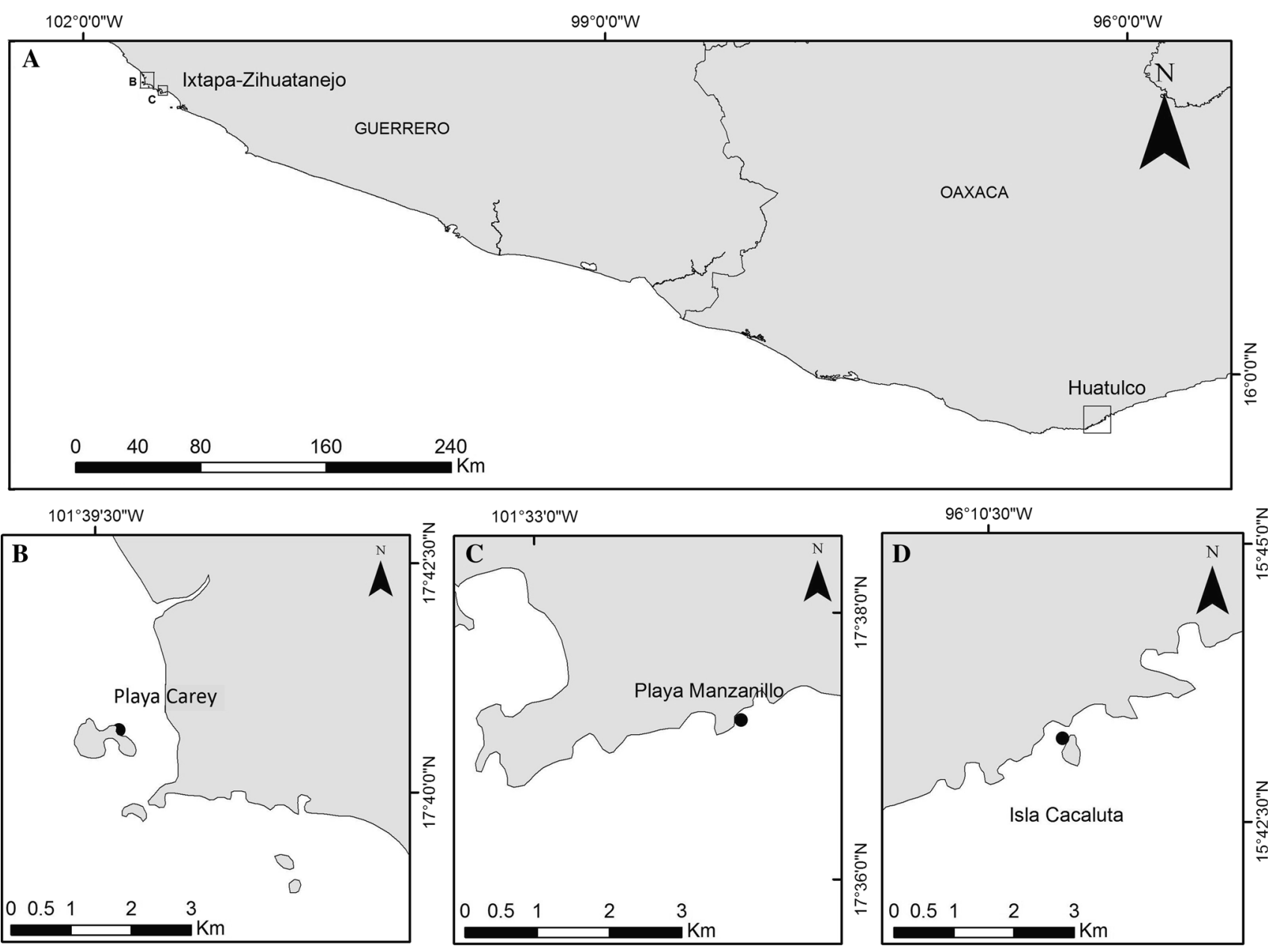

Fig. 1 Study sites: a general localization, b Playa Carey and c Playa Manzanillo in Ixtapa-Zihuatanejo and d Isla Cacaluta in Huatulco

\section{Materials and methods}

Field work

Rhodolith samples were obtained during field trips conducted from February to October of 2012. The material was collected at three study sites: Playa Carey $\left(17^{\circ} 62^{\prime} \mathrm{N}\right.$, $\left.101^{\circ} 52^{\prime} \mathrm{W}\right)$ and Playa Manzanillo $\left(17^{\circ} 67^{\prime} \mathrm{N}, 101^{\circ} 65^{\prime} \mathrm{W}\right)$ in Ixtapa-Zihuatanejo, Guerrero and Isla Cacaluta, Huatulco, Oaxaca $\left(15^{\circ} 43^{\prime} 08^{\prime \prime} \mathrm{N}, 96^{\circ} 09^{\prime} \mathrm{W}\right.$; Fig. 1). Depth ranges at these sites are shallow from 4 to $6 \mathrm{~m}$ depth. Their seabed is formed by sand and coral. The study sites are typical of the tropical eastern Pacific, and a full description regarding temperature, salinity and currents is given in López-Pérez et al. (2012).

\section{Laboratory work}

The collected material was preserved in $4 \%$ formalin in seawater and entered into the Phycological Herbarium of Universidad del Mar, Oaxaca, Mexico.
From each rhodolith collected, permanent slides were made for optical microscopy following the format of Riosmena-Rodríguez et al. (1999). The morphological and anatomical observations follow Woelkerling (1988). The determination to genera and species level followed descriptions by Dawson (1960), Chamberlain and Irvine (1994), Wilks and Woelkerling (1994, 1995) and Woelkerling (1996). Following the previously cited authors, the diagnostic features used to determine species were for Lithothamnion, the morphology and anatomy of the tetrasporangial conceptacle roof and the localization of old conceptacles according to the rounding vegetative tissue, while for Phymatolithon, the rhodolith growth morphology, anatomy of the tetrasporangial conceptacle roof and camera and localization of old conceptacles according to the rounding vegetative tissue. Type specimens were not examined. Typification data follow Woelkerling (1993). For each determined species, the diameter and length measurements from 30 randomly selected epithallial, subepithallial and vegetative cells were taken. Diameter and height of sporangial chambers and length of tetrasporangia 
were measured from ten randomly selected structures for each species. All measurements were taken using the software Axio Vision Rel. 4.8 from digital photographs.

The maximum length (L), shortest $(\mathrm{S})$ and intermediate (I) dimensions of all specimens collected were measured with a Vernier caliper $( \pm 0.01 \mathrm{~mm})$ to calculate rhodolith sphericity following the protocol of Sneed and Folk (1958). Growth form terminology follows Woelkerling et al. (1993). The branch density was estimated through the number of branches in $1 \mathrm{~cm}^{2}$ randomly located on each rhodolith surface. Five such quadrants were measured on each rhodolith. A rarefaction curve was established to obtain the representative sample size.

\section{Results}

Taxonomic accounts

Two species were identified: Lithothamnion muelleri Lenormand ex Rosanoff 1866 (Fig. 2) and Phymatolithon repandum (Foslie) Wilks \& Woelkerling 1994 (Fig. 3). Both species were recorded in all three studied sites.

Lithothamnion muelleri Lenormand ex Rosanoff, 1866: 101, pl. 6, figs 8-11 (Fig. 2).

Further references: Wilks and Woelkerling (1995:553-558), Woelkerling (1996:179-183).

Synonyms: See Wilks and Woelkeling (1995:554-555), Woelkerling (1996: 181).

Lectotype: CN (herb. Lenormand); from Western Port Bay, Victoria; collected by W. H. Harvey 1851 (communicated by F. Mueller). Lectotype designated by Woelkerling (1983: 193, figs. 30-33) and Wilks and Woelkerling (1995: 555, fig. 1A).

Isolectotypes: MEL 588439; L 941.149-249 (communicated by Lenormand) (Wilks and Woelkerling 1995).

\section{Description}

Plants are non-geniculate, thallus-forming free-living rhodoliths with lumpy to fructicose growth form (Fig. 2a). Nucleus is of stone, coral or fragments of others rhodoliths. Thallus is pseudoparenchymatous with dorsiventral internal construction. Monomerous thallus construction consists of a single system of branched filaments that forms a core, running more or less parallel to the substratum and a more peripheral region with portions of core filaments or their derivatives that curve outwards toward the thallus surface and terminate in a single layer of epithalial cells. Flared epithallial cells (Fig. 2b) measure 3-8 $\mu \mathrm{m}$ in diameter and
2-4 $\mu \mathrm{m}$ in length. Cellular elongation is below the subepithallial region. Subepithallial initials cells (Fig. 2b) are as long or longer $(2.8-5 \mu \mathrm{m}$ in diameter and $4.8-9.9 \mu \mathrm{m}$ diameter) than the cells immediately below them and measure 2.6-5.2 $\mu \mathrm{m}$ in diameter y 3.5-7.7 $\mu \mathrm{m}$ in length. Adjacent filaments are joined by cell fusions (Fig. 2c). Pit connections and trichocytes have not been observed.

Multiporate tetrasporangial conceptacles are raised in relation to the surrounding vegetative thallus surface; chambers 106-190 $\mu \mathrm{m}$ high and 220-466 $\mu \mathrm{m}$ in diameter (Fig. 2d, f). Roofs of tetrasporangial conceptacles are composed of 5-6 layers of cells. Filaments bordering pore canals of tetrasporangial conceptacle composed of cells that do not differ in size and shape from cells in other roof filaments. Tetrasporangial conceptacle pores are $7.5-10.5 \mu \mathrm{m}$ in diameter, surrounded by 6-7 cells (Fig. 2e). Mature tetrasporangia measure $25-50 \mu \mathrm{m}$ in diameter and 80-120 $\mu \mathrm{m}$ in length, containing four zonated arranged tetraspores (Fig. 2g). Multiporate tetrasporangial conceptacles are raised in relation to the surrounding vegetative thallus surface (Fig. 2h). The presence of senescent conceptacles was located in the central region of the thallus (Fig. 2i). Gametangial samples were not seen.

Material examined: Playa Manzanillo, Ixtapa-Zihuatanejo, Guerrero, Mexico (4-6 m deep, June and October 2012, M1II; Playa Carey Ixtapa-Zihuatanejo, Guerrero, Mexico (4-6 m deep, October 2012, N1V); Isla Cacaluta, Huatulco, Oaxaca, Mexico (10 m deep, May 2012, 21C, 27B).

\section{Comments}

The morphology of fructicose rhodoliths observed in the examined specimens agrees with descriptions of the species in the Gulf of California and Nicaragua (Robinson et al. 2013). Nevertheless, the morphology is distinct from specimens living in the Atlantic and Southern Australia, which presents a crustose to warty morphology (Woelkerling 1996; Henriques et al. 2011). With regard to the vegetative and reproductive characters evaluated in the thallus (Table 1), most agree with reports on the same species from the Gulf of California, Nicaragua, Southern Australia and Brazil (Woelkerling 1996; Henriques et al. 2011; Robinson et al. 2013). According to Robinson et al. (2013), L. muelleri occurs along the Eastern Pacific ocean from Washington (USA) to Costa Rica. The present record fills the gap in species distribution for the Eastern Pacific ocean between the Gulf of California and Nicaragua.

Phymatolithon repandum (Foslie) Wilks \& Woelkerling 1994:190, figs 1-10 (Fig. 3).

Further references: Woelkerling (1996). 


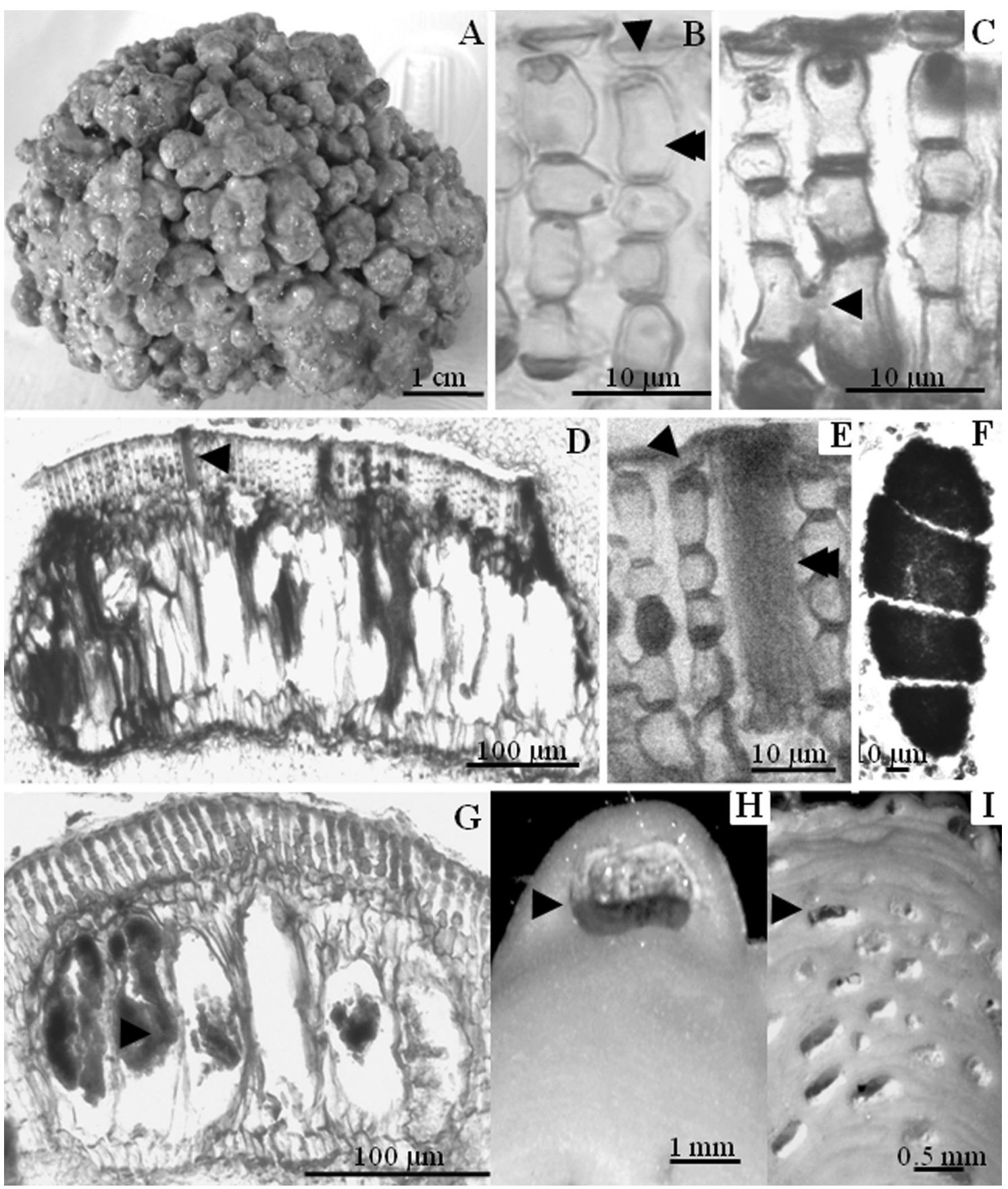

Fig. 2 Lithothamnion muelleri. Vegetative morphology and anatomy (longitudinal sections: b-i). a Fructicose growth form. b Flared epithallial cells (arrow) and subepithallial initials cells (double arrow). c Perithallial filaments with cell fusions between cells of adjacent filaments (arrow). d Multiporate tetrasporangial conceptacle roof shows a densely stained pore plug (arrow). e Pore canals (double arrow), note that roof cells adjacent to pore canals are similar in size and shape to other roof cells (arrow). f Zonated tetrasporangium. g Multiporate tetrasporangial conceptacle with zonated tetraspores (arrow). h Multiporate tetrasporangial conceptacle (arrow) is raised in relation to the surrounding vegetative thallus surface. i Senescent conceptacle in the central region of the thallus (arrow)
Synonyms: See Woelkerling (1996: 187,129).

Type locality: Half Moon Bay, Port Phillip Bay, Vic, Australia (Woelkerling 1996: 189).
Lectotype: TRH, unnumbered; includes slides 358 and 516; designated by Adey in Adey and Lebednik (1967) (Woelkerling 1996: 189). 


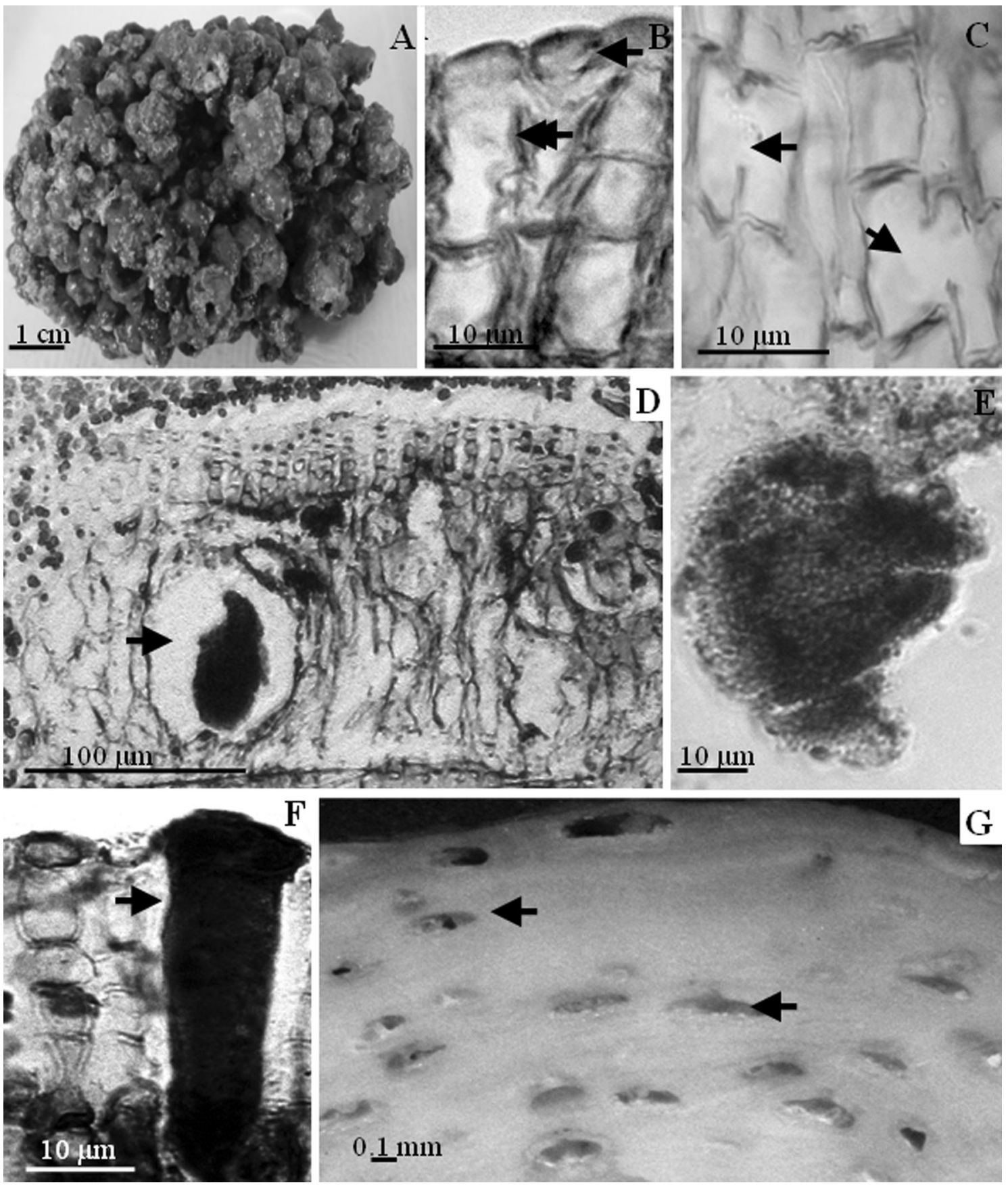

Fig. 3 Phymatolithon repandum. Vegetative morphology and anatomy (longitudinal sections: b-g). a Fructicose growth form. b Rounded epithallial cells (arrow) and subepithallial initials cells (double arrow). c Perithallial filaments with cell fusions between cells

\section{Description}

Plants are non-geniculate, thallus-forming free-living rhodoliths with lumpy to fructicose growth form. Nucleus is of stone, coral or fragments of other rhodoliths. Thallus is pseudoparenchymatous with dorsiventral internal construction. Monomerous thallus construction consists of a of adjacent filaments (arrow). d Multiporate tetrasporangial conceptacle with tetraspores (arrow). e Zonated tetrasporangium. f Pore canals (arrow). g Senescent conceptacle (arrow)

single system of branched filaments that forms a core, running more or less parallel to the substratum and a more peripheral region with portions of core filaments or their derivatives that curve outwards toward the thallus surface and terminate in a single layer of epithelial cells. Epithallial cells have a rounded wall (Fig. 3b) that measures $5-12 \mu \mathrm{m}$ in diameter and $2-5.8 \mu \mathrm{m}$ in length. Cellular 
Table 1 Comparative summary of information for L. muelleri and P. repandum for different geographical areas

\begin{tabular}{|c|c|c|c|c|c|c|c|c|}
\hline Species & Site & $\begin{array}{l}\text { Growth } \\
\text { form }\end{array}$ & $\begin{array}{l}\text { Thallus } \\
\text { construction }\end{array}$ & $\begin{array}{l}\text { Epithalial } \\
\text { cells } \\
\text { length } \\
(\mu \mathrm{m})\end{array}$ & $\begin{array}{l}\text { Epithalial } \\
\text { cells } \\
\text { diameter } \\
(\mu \mathrm{m})\end{array}$ & $\begin{array}{l}\text { Tetrasporangial } \\
\text { conceptacle } \\
\text { chamber height } \\
(\mu \mathrm{m})\end{array}$ & $\begin{array}{l}\text { Tetrasporangial } \\
\text { conceptacle } \\
\text { chamber diameter } \\
(\mu \mathrm{m})\end{array}$ & $\begin{array}{l}\text { Resource } \\
\text { information }\end{array}$ \\
\hline \multirow[t]{6}{*}{$\begin{array}{l}\text { Lithothamnion } \\
\text { muelleri }\end{array}$} & $\begin{array}{l}\text { Mexican } \\
\text { South } \\
\text { Pacific }\end{array}$ & $\begin{array}{l}\text { Lumpy to } \\
\text { fructicose }\end{array}$ & Monomerous & $2-4$ & $3-8$ & $106-190$ & $220-466$ & Present study \\
\hline & $\begin{array}{l}\text { Gulf of } \\
\text { California }\end{array}$ & $\begin{array}{l}\text { Lumpy to } \\
\text { fructicose }\end{array}$ & Monomerous & $2-5$ & $7-10$ & $100-210$ & $210-350$ & $\begin{array}{l}\text { Robinson } \\
\text { et al. } \\
\text { (2013) }\end{array}$ \\
\hline & Nicaragua & $\begin{array}{l}\text { Lumpy to } \\
\text { fructicose }\end{array}$ & Monomerous & $2-5$ & $7-10$ & $170-250$ & $350-700$ & $\begin{array}{l}\text { Robinson } \\
\text { et al. } \\
\text { (2013) }\end{array}$ \\
\hline & $\begin{array}{c}\text { Espírito } \\
\text { Santo } \\
\text { State, } \\
\text { Brazil }\end{array}$ & $\begin{array}{l}\text { Encrusting } \\
\text { to lumpy } \\
\text { to } \\
\text { fructicose }\end{array}$ & Monomerous & - & - & $150-190$ & $350-500$ & $\begin{array}{l}\text { Amado- } \\
\text { Filho et al. } \\
(2010)\end{array}$ \\
\hline & $\begin{array}{l}\text { Southern } \\
\text { Australia }\end{array}$ & $\begin{array}{l}\text { Crustose to } \\
\text { warty }\end{array}$ & Monomerous & $1-8$ & $2-8$ & $150-200$ & $280-750$ & $\begin{array}{l}\text { Woelkerling } \\
\text { (1996) }\end{array}$ \\
\hline & $\begin{array}{c}\text { Espírito } \\
\text { Santo } \\
\text { State, } \\
\text { Brazil }\end{array}$ & Warty & Monomerous & $4-6$ & $5-7$ & $200-320$ & $375-755$ & $\begin{array}{l}\text { Henriques } \\
\text { et al. } \\
(2011)\end{array}$ \\
\hline \multirow[t]{2}{*}{$\begin{array}{l}\text { Phymatolithon } \\
\text { repandum }\end{array}$} & $\begin{array}{l}\text { Mexican } \\
\text { South } \\
\text { Pacific }\end{array}$ & $\begin{array}{l}\text { Lumpy to } \\
\text { fructicose }\end{array}$ & Monomerous & $2-5.8$ & $5-12$ & $93-129$ & $271-377$ & Present study \\
\hline & $\begin{array}{l}\text { Southern } \\
\text { Australia }\end{array}$ & $\begin{array}{l}\text { Encrusting } \\
\text { to warty } \\
\text { to } \\
\text { fructicose }\end{array}$ & Monomerous & $2-8$ & $1-8$ & $50-150$ & $96-300$ & $\begin{array}{l}\text { Woelkerling } \\
\text { (1996) }\end{array}$ \\
\hline
\end{tabular}

elongation is below the subepithallial region. Subepithallial initial cells (Fig. 3b) are as short or shorter (4.3-9.5 $\mu \mathrm{m}$ in diameter and 2.2-8 $\mu \mathrm{m}$ diameter) as the cell immediately below them that measures $4-11 \mu \mathrm{m}$ in diameter and 3.9-10.5 $\mu \mathrm{m}$ in length. Adjacent filaments are joined by cell fusions (Fig. 3c). Pit connections and trichocytes have not been observed.

Multiporate tetrasporangial conceptacles are raised in relation to the surrounding vegetative thallus surface; chambers 93-129 $\mu \mathrm{m}$ high and 271-377 $\mu \mathrm{m}$ in diameter (Fig. 3d). Mature tetrasporangia measure 26-33 $\mu \mathrm{m}$ in diameter and 48-53 $\mu \mathrm{m}$ in length, containing four zonated arranged tetraspores (Fig. 3e). Tetrasporangial conceptacle pore is $5-8.6 \mu \mathrm{m}$ in diameter, surrounded by 6 cells (Fig. 3f). Mature conceptacles are not filled with enlarged irregularly shaped vegetative cells interspersed among the sporangia. Senescent conceptacles were located in central region of thallus (Fig. 3g). Gametangial samples were not seen.

Material examined: Playa Manzanillo, Ixtapa-Zihuatanejo, Guerrero, Mexico (4-6 m deep, June and October 2012, M1I; Playa Carey Ixtapa-Zihuatanejo, Guerrero, Mexico (4-6 m deep, October 2012, N2V, N1II); Isla
Cacaluta, Huatulco, Oaxaca, Mexico (10 m deep, May 2012, 27A).

\section{Comments}

The fructicose rhodolith morphology and the vegetative and reproductive characters measured in the examined specimens agree with characteristics cited for the species in Southern Australia (Woelkerling 1996). According to Woelkerling (1996), the species occurs from Eyre, West Australia to Cape Conran, Victoria, and Tasmania. The species has been recorded in the Western Pacific ocean in the Federated States of Micronesia (Lobban and Tsuda 2003) and Mariana Islands (Tsuda 2003). The present record is the first of this species in the Eastern Pacific ocean.

\section{Morphology account}

Rhodoliths belonging to $L$. muelleri and $P$. repandum were similar with regard to sphericity, size and branch density, independent of the sampled localities (Fig. 4; Table 2). 


\section{Discussion}

The non-geniculate coralline algae L. muelleri and $P$. repandum are reported for the first time for the Mexican South Pacific. For L. muelleri, the previous records from the Mexican Pacific are from the Gulf of California (Robinson et al. 2013), while for P. repandum, this is the first record of its presence in the Eastern Pacific.

The presence of the genus Lithothamnion in the Mexican South Pacific has been recorded previously, but with the species Lithothamnion phymatodeum Foslie 1902 (Dawson 1960; León-Álvarez and González-González 1993; Fragoso and Rodríguez 2002). The similarities between $L$. phymatodeum and the present recorded species

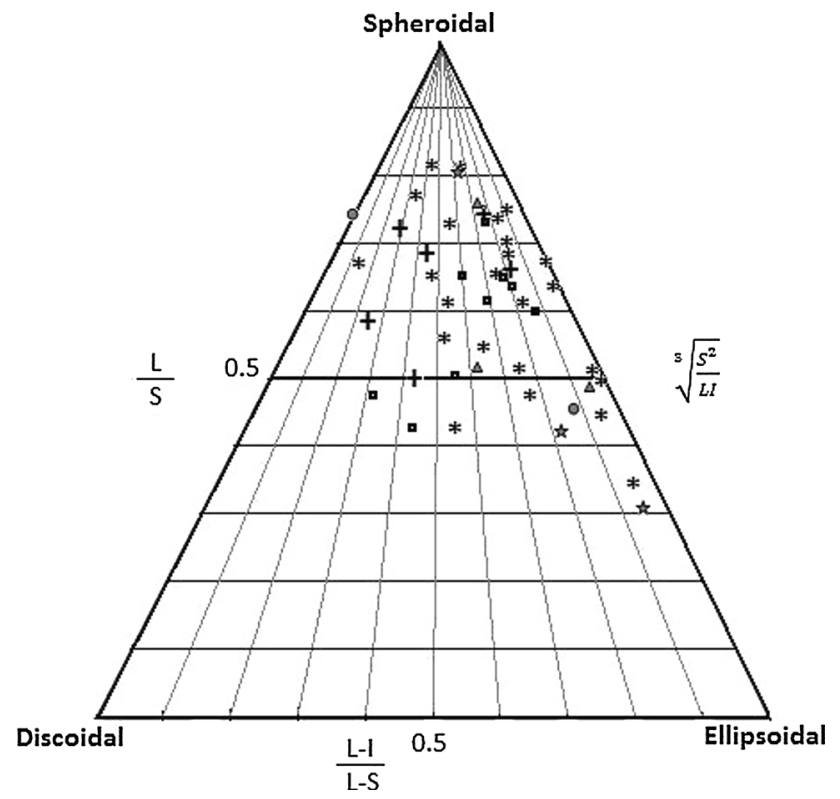

Fig. 4 Rhodolith sphericity, L. muelleri in Isla Cacaluta (asterisks), L. muelleri in Playa Manzanillo (crosses) and L. muelleri in Playa Carey (squares); $P$. repandum in Isla Cacaluta (triangles), $P$. repandum in Playa Mazanillo (points) and $P$. repandum in Playa Carey (stars). Each point represents the sphericity of one rhodolith. S, $\mathrm{I}$ and $\mathrm{L}$ correspond to shortest, intermediate and longest dimensions $(\mathrm{cm})$ of each individual, respectively. Equations shown were used to determine placement along each respective axis. Points nearest to the apex are most spherical
L. muelleri include a roof in mature tetrasporangial conceptacles not pitted with depressions and the pore canals bordered by cells that do not differ in size and shape from cells in other roof filaments (Dawson 1960; Masaki 1968; Woelkerling 1996; Fragoso and Rodríguez 2002). Nevertheless, the distinguished features reported in L. muelleri and observed in the examined material include the presence of the tetrasporangial roof usually not broken (Fig. 2d) and buried conceptacles (Fig. 2i) (Woelkerling 1996).

Regarding the presence of the genus Phymatolithon in the Mexican South Pacific, the only species reported is $P$. lenormandii (Areschoug) Adey 1966 (Dawson 1960; Huerta and Tirado 1970; León-Álvarez and González-González 1993; León-Tejera and González-González 1993; Mateo-Cid and Mendoza-González 2012). The particular characteristics cited for $P$. lenormandii include old conceptacles, not becoming buried (Chamberlain and Irvine 1994), and the absence of protuberances, with usually the thallus having a flat surface (Dawson 1960; Masaki 1968). The cited features were not observed in the studied material Phymatolithon. On the other hand, the characteristics of fructicose thallus and tetrasporangial conceptacle chambers-not filled with large, sterile cells, as reported for $P$. repandum (Woelkerling 1996) — match with the observed features in the studied specimens (Fig. 3d).

Bastida-Zavala et al. (2013) listed 21 non-geniculate corallines for the central part of the South Mexican Pacific. The present study increases the diversity of the group by $9.5 \%$; nevertheless, the numbers could increase after examination of new locations, for example in deeper water.

Finally, the rhodoliths generally showed a lower branch density value (1-3.8) in comparison with those reported for shallow water rhodoliths in the Gulf of California by Steller et al. (2003, 2009). The authors related such low values with low to moderate water movement commonly found in current rhodolith beds. Nevertheless, the high percentage of spheroidal rhodoliths found in the present study (Fig. 4) suggest evidence for stronger conditions and shorter waves in contrast to bottom currents (Foster 2001). In order to test this prediction, it will be necessary to increase the number of rhodoliths measured and to measure direct or indirect movement in the water column.
Table 2 Rhodolith maximum length and branch density

\begin{tabular}{|c|c|c|c|c|c|c|}
\hline \multirow[t]{2}{*}{ Sites } & \multicolumn{3}{|c|}{ Lithothamnion muelleri } & \multicolumn{3}{|c|}{ Phymatolithon repandum } \\
\hline & $\begin{array}{l}\text { Isla } \\
\text { Cacaluta } \\
n=24\end{array}$ & $\begin{array}{l}\text { Playa } \\
\text { Manzanillo } \\
n=6\end{array}$ & $\begin{array}{l}\text { Playa } \\
\text { Carey } \\
n=9\end{array}$ & $\begin{array}{l}\text { Isla } \\
\text { Cacaluta } \\
n=3\end{array}$ & $\begin{array}{l}\text { Playa } \\
\text { Manzanillo } \\
n=2\end{array}$ & $\begin{array}{l}\text { Playa } \\
\text { Carey } \\
n=3\end{array}$ \\
\hline Maximum length $(\mathrm{mm})$ & 79.92 & 73.1 & 52.98 & 70.29 & 43.1 & 63.19 \\
\hline $\begin{array}{l}\text { Maximum branch density } \\
\left(\text { branches } \mathrm{cm}^{2} \text { ) }\right.\end{array}$ & 2.57 & 3.8 & 3.4 & 2.43 & 3.4 & 3.2 \\
\hline $\begin{array}{l}\text { Minimum branch density } \\
\text { (branches } \mathrm{cm}^{2} \text { ) }\end{array}$ & 1 & 2.4 & 2 & 1.57 & 2.6 & 1.8 \\
\hline
\end{tabular}


Acknowledgments We are grateful to "Programa para el mejoramiento del Profesorado"-PROMEP-2011 for the financial support under the project "Rodolitos en el Pacífico sur de México: especies formadoras, tasa de crecimiento individual e invertebrados asociados". Also, we thank Dr. Norma A. López-Gómez and Dr. Candelaria F. Candelaria Silva from the Universidad Nacional Autónoma de México-Unidad Zihuatanejo for providing logistic support in the field and for reference to specialized literature. We are also grateful to the UMAR for administrative and logistic support. Finally, we are grateful to Dr. Florian Weinberger and both anonymous reviewers who have helped to improve the quality of the article.

\section{References}

Amado-Filho GM, Maneveldt GW, Pereira-Filho GH, Manso RCC, Bahia RG, Barros-Barreto MB, Guimaraes SMPB (2010) Seaweed diversity associated with a Brazilian tropical rhodolith bed. Cienc Mar 36:371-391

Bastida-Zavala JR, García-Madrigal MS, Rosas-Alquicira EF, LópezPérez RA, Benítez-Villalobos F, Meráz-Hernando A, TorresHuerta AM, Montoya-Márquez A, Barrientos-Luján N (2013) Marine and coastal biodiversity of Oaxaca, México. Check List 9:329-390

Chamberlain YM, Irvine LM (1994) Melobesioideae Bizzozero. In: Irvine LM, Chamberlain YM (eds) Seaweeds of the British Isles. Volume 1. Rhodophyta Part 2B Corallinales, Hildenbrandiales. HMSO, London, pp 159-234

Dawson EY (1960) Marine red algae of Pacific Mexico. Part 3. Cryptonemiales, Corallinaceae subf. Melobesioideae. Pac Nat 2:3-125

Foster MS (2001) Rhodoliths: between rocks and soft places. J Phycol 37:659-667

Fragoso D, Rodríguez D (2002) Algas coralinas no geniculadas (Corallinales, Rhodophyta) en el Pacífico tropical mexicano. Anales Inst Biol Univ Nac Autón México Bot 73:97-136

Harvey AS, Woelkerling WJ (2007) Guía de identificación de rodolitos de algas rojas coralinas no geniculadas (Corallinales, Rhodophyta). Cienc Mar 33:411-426

Henriques MC, Villas-Boas A, Riosmena-Rodríguez R, Figueiredo MAO (2011) New records of rhodolith-forming species (Corallinales, Rhodophyta) from deep water in Espírito Santo State, Brazil. Helg Mar Res 66:219-231

Huerta ML, Tirado J (1970) Estudio florístico-ecológico de las algas marinas de la costa del Golfo de Tehuantepec, México. Bol Soc Bot Méx 31:113-137

León-Álvarez D, González-González J (1993) Algas costrosas del Pacífico Tropical. In: Salazar-Vallejo I, González EN (eds) Biodiversidad marina y costera de México. CONABIO y CIQRO, México, pp 456-474

León-Tejera H, González-González J (1993) Macroalgas de Oaxaca. In: Salazar-Vallejo SI, González NE (eds) Biodiversidad Marina y Costera de México. CONABIO y CIQRO, México, pp 486-498

Lobban CS, Tsuda RT (2003) Revised checklist of benthic marine macroalgae and seagrasses of Guam and Micronesia. Micronesica 35(36):54-99
López-Pérez RA, Calderón-Aguilera LE, Reyes-Bonilla H, Carriquiry JD, Medina-Rosas P, Cupul-Magaña AL, Herrero-Pérezrul MD, Hernández-Ramírez HA, Áhumada-Sempoal MÁ, Luna-Salguero BM (2012) Coral communities and reefs from Guerrero, Southern Mexican Pacific. Mar Ecol 33:407-416

Masaki T (1968) Studies on the Melobesioideae of Japan. Mem Fac Fish Hokkaido Univ 16:1-80

Mateo-Cid LE, Mendoza-González AC (2012) Algas marinas bentónicas de la costa noroccidental de Guerrero, México. Rev Mex Biodiv 83:905-928

Mendoza-González AC, Mateo-Cid LE (1998) Avance de un estudio sobre las macroalgas marinas de Guerrero y Oaxaca. Ciencia y Mar 4:15-29

Riosmena-Rodríguez R, Woelkerling WJ, Foster MS (1999) Taxonomic reassessment of rhodolith-forming species of Lithophyllum (Corallinales, Rhodophyta) in the Gulf of California, México. Phycology 38:401-417

Robinson NM, Hansen GI, Fernández-García C, Riosmena-Rodríguez R (2013) A taxonomic and distributional study of the rhodolithforming species Lithothamnion muelleri (Corallinales, Rhodophyta) in the Eastern Pacific Ocean. Algae 28:63-71

Sneed ED, Folk RL (1958) Pebbles in the lower Colorado River, Texas; a study in particle morphogenesis. J Geol 66:114-150

Steller DL, Riosmena-Rodríguez R, Foster MS, Roberts CA (2003) Rhodolith bed diversity in the Gulf of California: the importance of rhodolith structure and consequences of disturbance. Aquat Conserv Mar Freshw Ecosyst 13:S5-S20

Steller DL, Riosmena-Rodríguez R, Foster MS (2009) Living rhodolith bed ecosystems in the Gulf of California. In: Johnson ME, Ledesma-Vázquez J (eds) Atlas of coastal ecosystems in the western Gulf of California. University of Arizona Press, United States

Tsuda RT (2003) Checklist and bibliography of the marine benthic algae from the Mariana Islands (Guam and CNMI). Technical report. University of Guam Marine Laboratory 107: i-v, 1-49

Wilks KM, Woelkerling WJ (1994) An account of southern Australian species of Phymatolithon (Corallinaceae, Rhodophyta) with comments on Leptophytum. Aust Syst Bot 7:183-223

Wilks KM, Woelkerling WJ (1995) An account of southern Australian species of Lithothamnion (Corallinaceae, Rhodophyta). Aust Syst Bot 8:549-583

Woelkerling WJ (1988) The coralline red algae: an analysis of the genera and subfamilies of nongeniculate Corallinaceae. University Press, London

Woelkerling WJ (1993) Type collections of Corallinales (Rhodophyta) in the Foslie Herbarium (TRH). Gunneria 67:1-289

Woelkerling WJ (1996) Subfamily Melobesioideae. In: Womersley HBS (ed) The Marine Benthic Flora of Southern Australia-Part IIIB. Gracilariales, Rhodymeniales, Corallinales and Bonnemaisoniales. Australian Biological Resources Study, Canberra, pp 164-210

Woelkerling WJ, Irvine LM, Harvey AS (1993) Growth-forms in nongeniculate coralline red algae (Corallinales, Rhodophyta). Aust Syst Bot 6:277-293 